\title{
Recharge characterization by geoelectrical imaging and the GIS of the Plio-Quaternary aquifer (a case study of Central Haouz- Marrakesh)
}

\author{
Meriem Snineh, PhD Reseacher \\ Associated Unit of Research to CNRST (GEOHYD-URAC44) \& National \\ center of Studies and Research about Water and Energy, Cadi Ayyad \\ University, Marrakesh, Morocco
}

Khalid Mehdi, Professor

Mohammed Bouzerda, Phd Reseacher

Associated Unit of Research to CNRST (LGMSS-URAC45), Chouaib

Doukkali University, Faculty of Sciences El Jadida, Morocco.

\section{Said El Goumi, PhD Reseacher \\ Nour-Eddine Laftouhi, Professor}

Associated Unit of Research to CNRST (GEOHYD-URAC44), Cadi Ayyad

University, Faculty of Sciences Semlalia, Marrakesh, Morocco.

Abdennabi El Mandour, (Professor)

Director of Mohamed VI Museum of Water Civilisation in Morocco,

Ministry of Habous and Islamic Affairs, Marrakesh

Doi:10.19044/esj.2020.v16n12p316 URL:http://dx.doi.org/10.19044/esj.2020.v16n12p316

\begin{abstract}
Groundwater resources in Morocco are increasingly scarce. The study area which is Central Haouz belonging to the Marrakech plain is not immune to this phenomenon. This is due to the semi-arid climate on the one hand, and on the other hand, due to accelerated population growth and the economic development implications. The Plio-Quaternary aquifer of the Central Haouz has been the subject of several studies, but its Hydrogeological characterization has been classically carried out using geological and pumping test studies. Our study is in this sense to show the importance of the contribution of GIS and Electrical Resistivity Tomography (ERT). The first GIS approach determined the Runoff coefficient, which helps to locate low runoff areas corresponding to recharge zones of the water table. These areas are chosen as the site for geophysical surveys. The second method consists to detect the effect of the recharge to increase the water table in the study area and the characterization of the aquifer. Four ERT surveys were performed showed on the aquifer the positive effect of the recharge dike recently built at
\end{abstract}


the Wadi and dismantle the reliability of the GIS results concerning the infiltration zones founded.

Keywords: Electrical Resistivity Tomography (ERT), Runoff coefficient, GIS, Haouz central, Plio-Quaternary aquifer, Hydrogeological characterization

\section{Introduction}

The central Haouz plain, covering an area of $2300 \mathrm{~km}^{2}$, is located in southwest Morocco. It occupies a depression between two very distinct major structural domains: the Atlas Mountains in the South and the Jbiletes Ranges in the North (Fig. 2).

This study focuses on the region of Sidi Abdellah Ghiat, which is located about 20 kilometers from Marrakech in the south-southeast of the central Haouz plain. The water resources of this area have two major challenges. The first is of an economic nature since the region's development is essentially based on agriculture, which requires an increasing mobilization of water resources, with increasing use of irrigation from wells. The second issue is of a climatic nature given the persistence of years of drought, leading to a significant drop in the water table. These resources have been overexploited over the years.

Two types of groundwater with distinct water potential characterize the study area. The geometric and structural characterization of these aquifer systems remains poorly known despite geological and hydrogeological exploration undertaken by several authors (Ambroggi et al., 1952; Bernert et al., 1972). In recent years, other research has focused on the functioning of the Plio-Quaternary aquifer using the chemical, isotopic and GIS tool (Kabbaj, 1978; DGH 1994; Chellai et Perriaux, 1996; C.S.E.C. 2001; Abourida, 2007). Although the results of these studies are of great importance, the lack of indepth understanding of aquifer geometry limits certain interpretations of the terms of water resources management in the region. Particularly in the case of the study of preferential drainage and recharge zones, the lateral dispersion of the natural and artificial recharge and the relationship between deep and shallow aquifers. Groundwater resources in the Sidi Abdellah Ghiat region (Central Haouz) are being depleted. To reduce the effect of overexploitation of surface aquifer waters, the use of deep aquifer waters remains a timely solution, but as long as the cost of deep drilling up to $120 \mathrm{~m}$ is quite expensive, it will be possible to use less expensive water installations built with local products. This hydraulic installation is a retention dike built at the Wadis to create a considerable residence time to tributaries and subsequently recharge the water table by Wadi. It is an alternative to partially fill the water deficit observed in the region. 
This study proposes to address this alternative solution and highlight its positive effect. To do this, we will mainly rely on the combination of the contribution of Electrical Tomography and the GIS Geographic Information System to the structural characterization of the subsoil on the one hand and the evaluation of the potentialities in water resources on the other hand. The final objective is to define potentially rechargeable areas that could constitute pockets of groundwater supply.

\section{Materials et methods}

\subsection{Overview of the study area}

The sector studied is part of the Plio-Quaternary plain of Haouz central portion of the Tensift catchment area (Michard, 1976; Piqué et Michard, 1981). It consists of a vast corridor of plains of about $2300 \mathrm{~km} 2$ extending from east to west in parallel with the syncline corridor north of the Jbiletes between longitudes $8^{\circ} 22^{\prime} \mathrm{W}$ and $7^{\circ} 30^{\prime} \mathrm{W}$ and latitudes $31^{\circ} 43^{\prime} \mathrm{N}$ and $31^{\circ} 12^{\prime} \mathrm{N}$ (Fig.1).

The Central Haouz is a plain bounded to the North by the Jbiletes ranges and to the South by the mountain ranges of the High Atlas, by the R'Dat Wadi in the East and by the N'Fis Wadi in the West (Fig.1).

The sector is located in the NE part of the plain by taking the national road $n^{\circ} 9$ linking Marrakech to Ouarzazate, about 20 kilometers away.

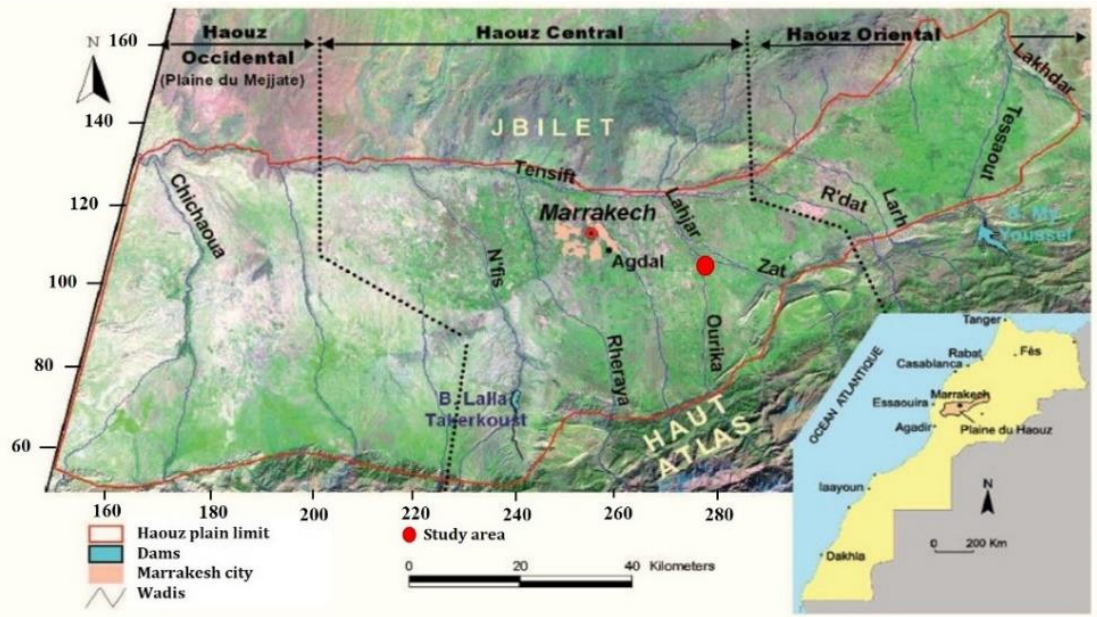

Figure 11 : Location of the study area

\subsection{Geological Framework}

The Haouz plain is in the form of a depression (fig. 2) where important detrital detritical formations, resulting from the dismantling of the atlasic chain, accumulated from Neogene to the recent Quaternary, thus covering the primary, secondary and tertiary formations (Moukhchane, 1983; Sinan, 2000). From East to West of the Central Haouz, the geological series has a variable 
thickness (fig. 3). These formations are discordant on a substratum made up of a Hercynian base which outcrops in favor of the Palaeozoic massifs of Jebilets and Guemassa. The Haouz basin corresponds to a tectonic pit created by tectonic movements of faults and flexures linked to the uplift of the High Atlas in the OligoMiocene (Dutour \& Ferrandini, 1985). Indeed, during this period, the wadis accumulated the products of dismantling the chain in this pit, drowning the main architectural lines. These wadis spread their alluvium by lateral displacement of their courses in a shallow depression transformed into a spreading zone. Their deposits became increasingly fine downstream.

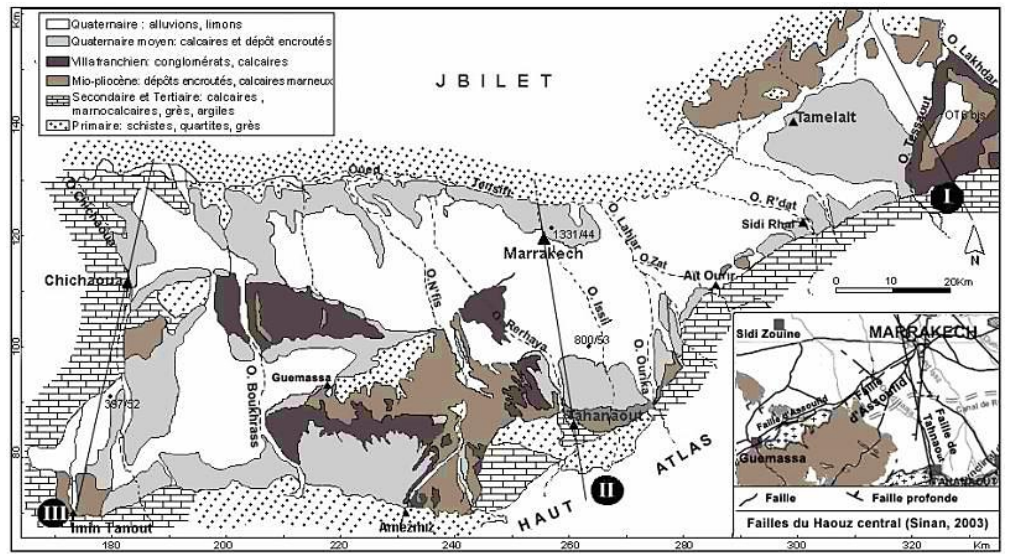

Figure 12 : Simplified geological map of Haouz (Based on map 1/500000 of Marrakech)

All the floors of the geological series from the primary to the recent quaternary are observable either on the edges of the plain or at any point of outcrop or at the level of some deep boreholes up to 120m deep (Moukhchane, 1983; Sinan, 2000).

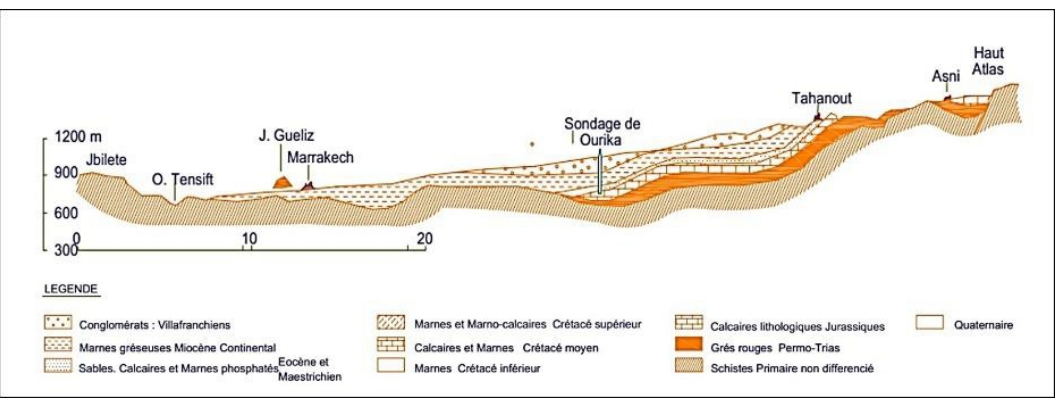

Figure 13 : Geological section II through the central Haouz and the northern edge of the High Atlas (Ambroggi et Thuile 1952)

Based on the existing boreholes near the study area, formations ranging from the Miocene to the recent Quaternary can be observed with the following characteristics (Fig. 4): 
The Mio-Pliocene is formed by detrital continental deposits with large lateral variations in facies and a thickness that decreases towards the north and west (Chellai, 1995; Chellai \& Perriaux, 1996). It is mainly formed by sandstone; cemented conglomerates (Dutour \& Ferrandini, 1985) and marly in the South and becomes sandstone at Ait Ourir. Towards the North the facies changes rapidly and becomes clayey-sands. The Mio-Pliocene forms the substratum of the water table with a significant power of about 274 meters of clay and marl between the Ourika and the Lkhdar Wadi, which decreases to 121 meters in the Western Haouz to the west (Sinan, 2000).

The Plio-Villafranchian is generally characterized by lateral variations of facies from South to North. It is mainly formed by polygenic conglomerates, conglomeratic limestone, nodule silts, calcareous crusts and finally noduleous or compact limestone (Freytet, 1984; Dutour et al., 1985).

The Quaternary, whose sediments are much diversified because they result from the dismantling products of the atlasic chain by a set of Wadis leading to the plain, where the gravitational deposition of the carried elements takes place. Quaternary sediments are represented by red silts, clays and pebbles and by conglomerates and alluvium at the banks of the Wadis (Razoki, 2001).

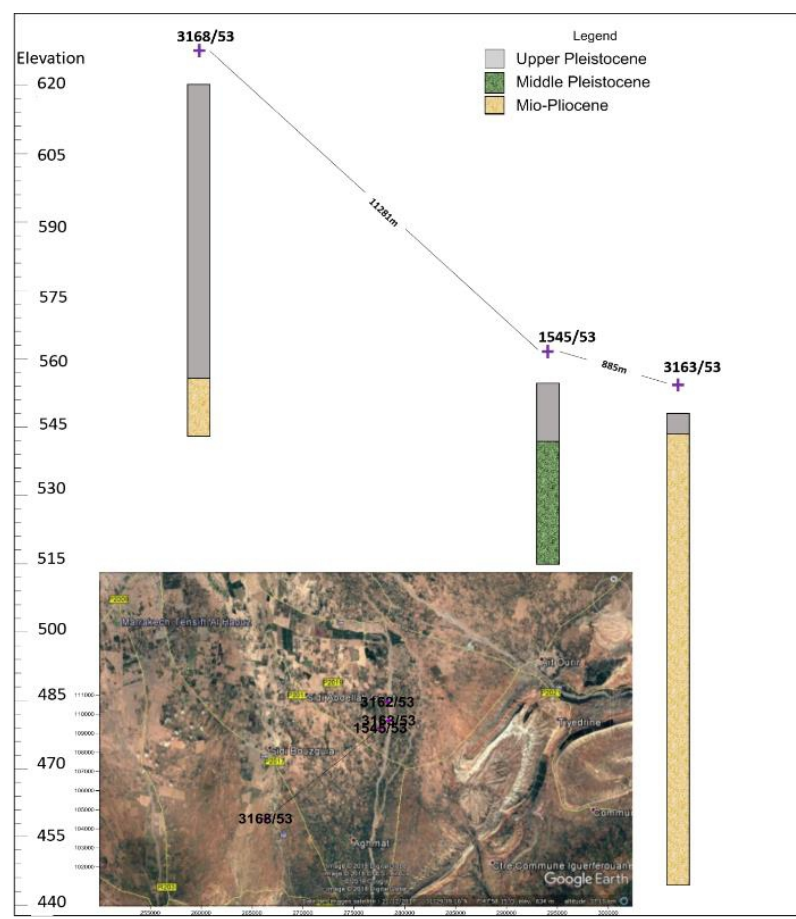

Figure 14: Existing reconnaissance drilling in the study area carried out by starter3 (ABHT data) 


\begin{tabular}{|c|c|c|c|}
\hline $\begin{array}{l}\text { Divisisin } \\
\text { gobloginue }\end{array}$ & & Lithofacies & \begin{tabular}{|l|} 
Epaisscur \\
maximale
\end{tabular} \\
\hline Quaternaire rizent & б0000 & Solls- grantrs - limoss $(50 \mathrm{~m})$ & $50 \mathrm{~m}$ \\
\hline \begin{tabular}{|l|} 
Hilafranthinan \\
\end{tabular} & 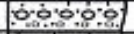 & Congleninat $(100 \mathrm{~m})$ & $100 \mathrm{~m}$ \\
\hline Nitģia: & 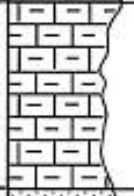 & 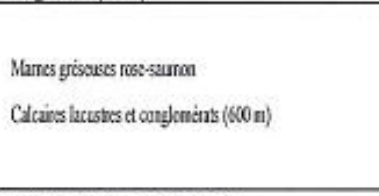 & $600 \mathrm{mt}$ \\
\hline 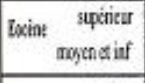 & & 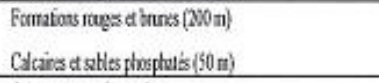 & $\begin{array}{l}200 \mathrm{~m} \\
50 \mathrm{~m} \\
\end{array}$ \\
\hline 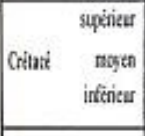 & $\mid \frac{1}{\frac{1}{2 \pi / 2}}$ & 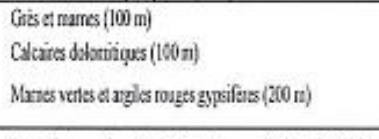 & $\begin{array}{l}100 \mathrm{~m} \\
100 \mathrm{~m} \\
200 \mathrm{~m}\end{array}$ \\
\hline 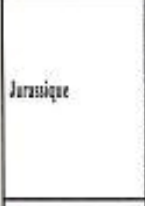 & 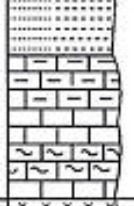 & 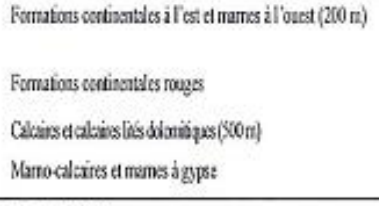 & $\begin{array}{l}200 \mathrm{~m} \\
300 \mathrm{~m}\end{array}$ \\
\hline Skphan:Tros & 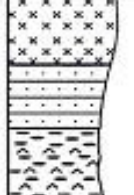 & 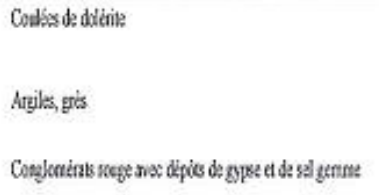 & $1200 \mathrm{~m}$ \\
\hline Prain & & Sthistes, gis etcuartzits & $6600 \mathrm{a} 8000 \mathrm{~m}$ \\
\hline
\end{tabular}

Figure 15: Lithostratigraphic series (Razoki, 2001)

\subsection{Hydrology framework}

At the central Haouz the flow regime is irregular depending on the rainfall of the watersheds forming it as well as the melting snow of the High Atlas. The hydrographic network of this part of Haouz is moderately dense starting in the High Atlas (N'Fis, Reghaya, Ourika and Zat) collected by the Tensift Wadi which discharges it towards the Ocean.

According to Chaponnière in 2005, the central Haouz has two parts. The northern flank occupied by the watersheds which is a part of production as long as it is well watered by the Wadis and significant precipitation (rain and snow under the effect of altitude).

The second flank corresponds to the central plain of Haouz characterized by a strong agglomeration and a developed agricultural activity which makes it a zone of consumption or transit 


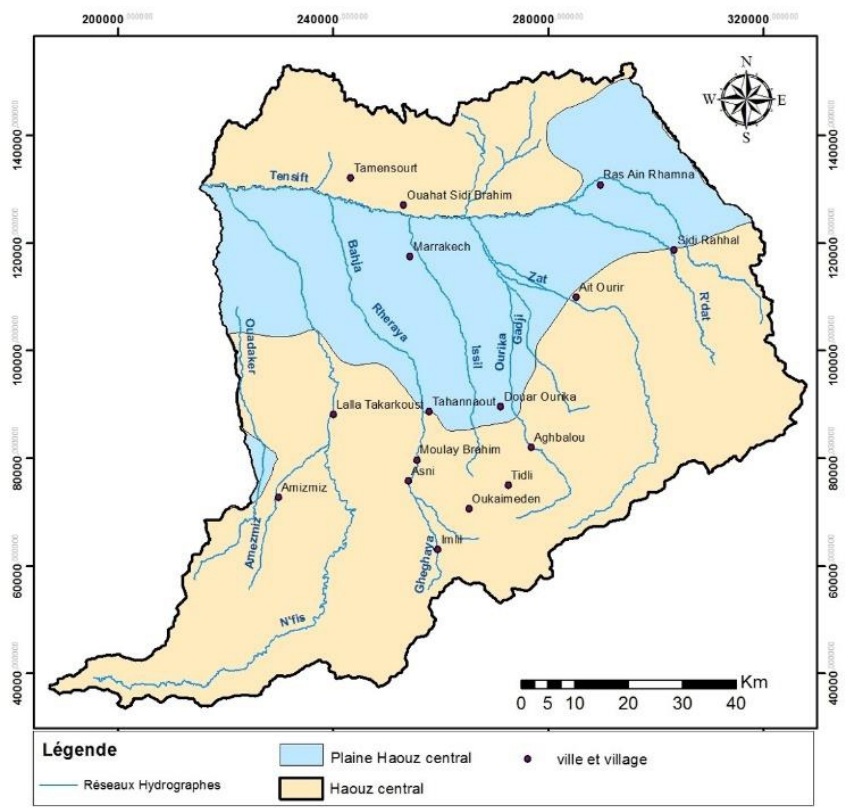

Figure 16: Haouz Central hydrographic networks

\subsection{Determination of Runoff Coefficient by GIS}

The idea of using the runoff coefficient is to determine the behavior of the Ourika-Zat watershed in terms of precipitation. The areas of maximum infiltration correspond to recharge areas of the Plio-Quaternary aquifer that will also be the subject of the Electric Tomography surveys.

The recent development of GIS and remote sensing technology makes it possible to capture and manage a large number of spatially distributed hydrological parameters and variables. GIS was used to create a distributed parameter hydrological model that is structured to characterize watershed conditions such as topography, soil type, land use, drainage density, soil saturation and rainfall properties. To do this, we used the WetSpa Extension.

WetSpa Extension is a physically based and distributed hydrological model to predict the transfer of water and energy between soil, plants and atmosphere at the regional or basin scale developed at the University Vrije Brussels, Belgium (Wang et al., 1997; Batelaan et al., 1996). The basin is divided into a number of grid cells to deal with heterogeneity. Each cell is divided into bare soil and a vegetated part, for which the water and energy balance is maintained. Figure 6 shows schematically the hydrological processes considered. The movement of water in the ground is simplified as a one-dimensional vertical flow, including surface infiltration, percolation and capillary rise in the unsaturated zone and recharge to groundwater. The model was designed to simulate Horton's land flow and the concept of a variable source area for the production of runoff water. To have a more realistic 
representation of the interaction between surface runoff and groundwater storage.

Arcgis 10.3 was used as a GIS tool to superimpose land use maps, soil type, slope, precipitation intensity and soil moisture. These variables undoubtedly act but also interact on the runoff coefficient. Tables 1 and 2 show the different combinations between these variables. Water lost at the soil surface is considered to be infiltrated into the soil used for the pursuit of vertical percolation, evapotranspiration and lateral flow. To simplify the table, the original land use classes are reclassified into five categories: forest, grass, crop, bare soil and impermeable area. The values in the tables below have been taken from the documents published in the various literature references (Browne, 1990; Chow et al., 1988; Mahmoud, 2014; Fetter, 1981).

Table 1: Potential of the Runoff coefficient for different land uses, soil type and slope

\begin{tabular}{llllllllllllll}
\hline $\begin{array}{l}\text { Land } \\
\text { use }\end{array}$ & $\begin{array}{l}\text { Slope } \\
(\%)\end{array}$ & Sand & $\begin{array}{l}\text { Loamy } \\
\text { sand }\end{array}$ & $\begin{array}{l}\text { Sandy } \\
\text { loam }\end{array}$ & Loam & $\begin{array}{l}\text { Silt } \\
\text { loam }\end{array}$ & Silt & $\begin{array}{l}\text { Sandy } \\
\text { clay } \\
\text { loam }\end{array}$ & $\begin{array}{l}\text { Clay } \\
\text { loam }\end{array}$ & $\begin{array}{l}\text { Silty } \\
\text { clay } \\
\text { loam }\end{array}$ & $\begin{array}{l}\text { Sandy } \\
\text { clay }\end{array}$ & $\begin{array}{l}\text { Silty } \\
\text { clay }\end{array}$ & Clay \\
\hline Forest & $<0,5$ & 0.03 & 0.07 & 0.10 & 0.13 & 0.17 & 0.20 & 0.23 & 0.27 & 0.30 & 0.33 & 0.37 & 0.40 \\
& $0,5-5$ & 0.07 & 0.11 & 0.14 & 0.17 & 0.21 & 0.24 & 0.27 & 0.31 & 0.34 & 0.37 & 0.41 & 0.44 \\
& $5-10$ & 0.13 & 0.17 & 0.20 & 0.23 & 0.27 & 0.30 & 0.33 & 0.37 & 0.40 & 0.43 & 0.47 & 0.50 \\
& $>10$ & 0.25 & 0.29 & 0.32 & 0.35 & 0.39 & 0.42 & 0.45 & 0.49 & 0.52 & 0.55 & 0.59 & 0.62 \\
\hline Grass & $<0,5$ & 0.13 & 0.17 & 0.20 & 0.23 & 0.27 & 0.30 & 0.33 & 0.37 & 0.40 & 0.43 & 0.47 & 0.50 \\
& $0,5-5$ & 0.17 & 0.21 & 0.24 & 0.27 & 0.31 & 0.34 & 0.37 & 0.41 & 0.44 & 0.47 & 0.51 & 0.54 \\
& $5-10$ & 0.23 & 0.27 & 0.30 & 0.33 & 0.37 & 0.40 & 0.43 & 0.47 & 0.50 & 0.53 & 0.57 & 0.60 \\
& $>10$ & 0.35 & 0.39 & 0.42 & 0.45 & 0.49 & 0.52 & 0.55 & 0.59 & 0.62 & 0.65 & 0.69 & 0.72 \\
\hline Crop & $<0,5$ & 0.23 & 0.27 & 0.30 & 0.33 & 0.37 & 0.40 & 0.43 & 0.47 & 0.50 & 0.53 & 0.57 & 0.60 \\
& $0,5-5$ & 0.27 & 0.31 & 0.34 & 0.37 & 0.41 & 0.44 & 0.47 & 0.51 & 0.54 & 0.57 & 0.61 & 0.64 \\
& $5-10$ & 0.33 & 0.37 & 0.40 & 0.43 & 0.47 & 0.50 & 0.53 & 0.57 & 0.60 & 0.63 & 0.67 & 0.70 \\
& $>10$ & 0.45 & 0.49 & 0.52 & 0.55 & 0.59 & 0.62 & 0.65 & 0.69 & 0.72 & 0.75 & 0.79 & 0.82 \\
\hline Bare & $<0,5$ & 0.33 & 0.37 & 0.40 & 0.43 & 0.47 & 0.50 & 0.53 & 0.57 & 0.60 & 0.63 & 0.67 & 0.70 \\
soil & $0,5-5$ & 0.37 & 0.41 & 0.44 & 0.47 & 0.51 & 0.54 & 0.57 & 0.61 & 0.64 & 0.67 & 0.71 & 0.74 \\
& $5-10$ & 0.43 & 0.47 & 0.50 & 0.53 & 0.57 & 0.60 & 0.63 & 0.67 & 0.70 & 0.73 & 0.77 & 0.80 \\
& $>10$ & 0.55 & 0.59 & 0.62 & 0.65 & 0.69 & 0.72 & 0.75 & 0.79 & 0.82 & 0.85 & 0.89 & 0.92 \\
\hline IMP & & 1.00 & 1.00 & 1.00 & 1.00 & 1.00 & 1.00 & 1.00 & 1.00 & 1.00 & 1.00 & 1.00 & 1.00 \\
\hline
\end{tabular}

Table 2: Slope constant S0 for determining the potential runoff coefficient

\begin{tabular}{lcccccccccccc}
\hline Land use & Sand & $\begin{array}{l}\text { Loamy } \\
\text { sand }\end{array}$ & $\begin{array}{l}\text { Sandy } \\
\text { loam }\end{array}$ & Loam & $\begin{array}{l}\text { Silt } \\
\text { loam }\end{array}$ & Silt & $\begin{array}{l}\text { Sandy } \\
\text { clay } \\
\text { loam }\end{array}$ & $\begin{array}{l}\text { Clay } \\
\text { loam }\end{array}$ & $\begin{array}{l}\text { Silty } \\
\text { clay } \\
\text { loam }\end{array}$ & $\begin{array}{l}\text { Sandy } \\
\text { clay }\end{array}$ & $\begin{array}{l}\text { Silty } \\
\text { clay }\end{array}$ & Clay \\
\hline Forest & 0.680 & 0.650 & 0.620 & 0.590 & 0.560 & 0.530 & 0.500 & 0.470 & 0.440 & 0.410 & 0.380 & 0.350 \\
Grass & 0.580 & 0.551 & 0.522 & 0.493 & 0.464 & 0.435 & 0.405 & 0.376 & 0.347 & 0.318 & 0.289 & 0.260 \\
Crop & 0.500 & 0.471 & 0.442 & 0.413 & 0.384 & 0.355 & 0.325 & 0.267 & 0.267 & 0.238 & 0.209 & 0.180 \\
Bare & 0.420 & 0.393 & 0.365 & 0.338 & 0.311 & 0.284 & 0.256 & 0.202 & 0.202 & 0.175 & 0.147 & 0.120 \\
\hline
\end{tabular}

In order to estimate the potential flow coefficient on the basis of a continuous slope, a simple linear relationship between the flow potential coefficient and the slope of the surface is used, which can be described in the equation (1) (Liu et De Smedt, 2003; Sharma, 1986). 


$$
C=C_{0}+\left(1-C_{0}\right)^{S} / S+S_{0}
$$

Where (C) is the runoff coefficient for the surface of a slope $(\mathrm{S})$ in $(\%)$. (C0) is the coefficient of flow potential for a near zero slope corresponding to the values quoted in first position in Table 1 for each class in the domain, and S0 (\%) is a constant slope of different land use and soil type combinations, as shown in Table 2, taking Table 1 as an extending element.

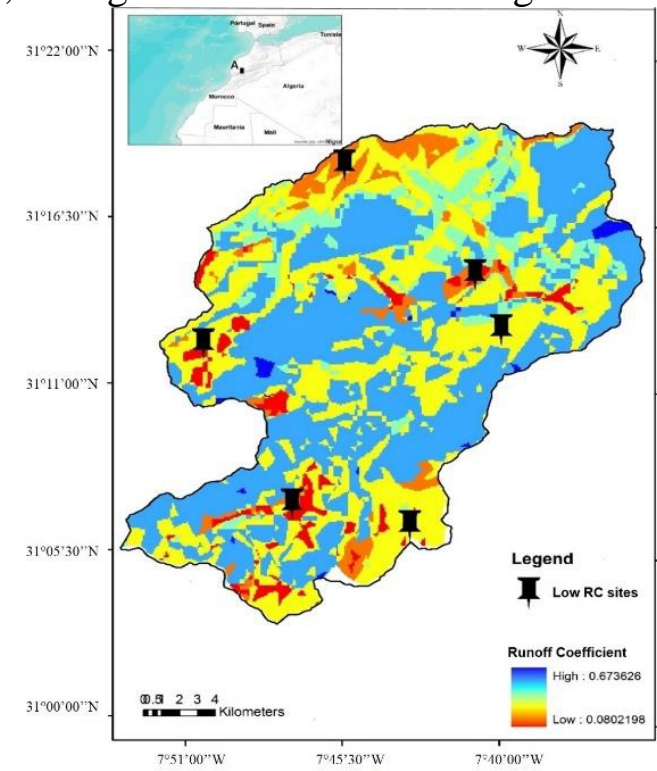

Figure 17 : Runoff coefficient distribution

\subsection{Geoelectrical data acquisition}

The electric imaging (or tomography) technique is an investigative method non-destructive to obtain an image of the subsoil in order to identify its internal structure such as geological heterogeneities, faults, depth and the thickness of the layers. Offering the possibility of acquiring a large number of measurements corresponding to the different combinations of four electrodes (Edwards, 1977; Asfahani \& al., 2013). This allows continuous 2D or 3D imaging of variations in subsoil resistivity (Dahlin, 2001) in regions with complex geology characterized by lateral variations that make the use of electrical boreholes inadequate (Giang et al., 2013).

The prospecting by electric tomography was initially planned according to a grid of several profiles targeting mainly the areas of high permeability on the bed of the Wadi Ourika passing through the village of Sidi Abdellah Ghiat. A Syscal Pro Switch 72 resistivimeter operating in multielectrode mode was used to carry out this work. This device has been configured to take measurements automatically in Wenner-Shlumberger configuration. To do this, we deployed a device of 72 electrodes spaced five 
meters apart, representing a line length of 350 meters. Before going to the field, we obviously programmed the measurement sequence using the ElectrePro software, opting for a level number that allows us to image the subsoil up to a depth of about sixty meters. Given the objective of the study, we chose to measure resistivity only. The four profiles deployed in an organized manner to highlight the effect of the recharge dike, profile 1 and 3 were placed perpendicular to the dike while profile 2 and 4 were placed parallel to the dike one upstream and the other downstream.

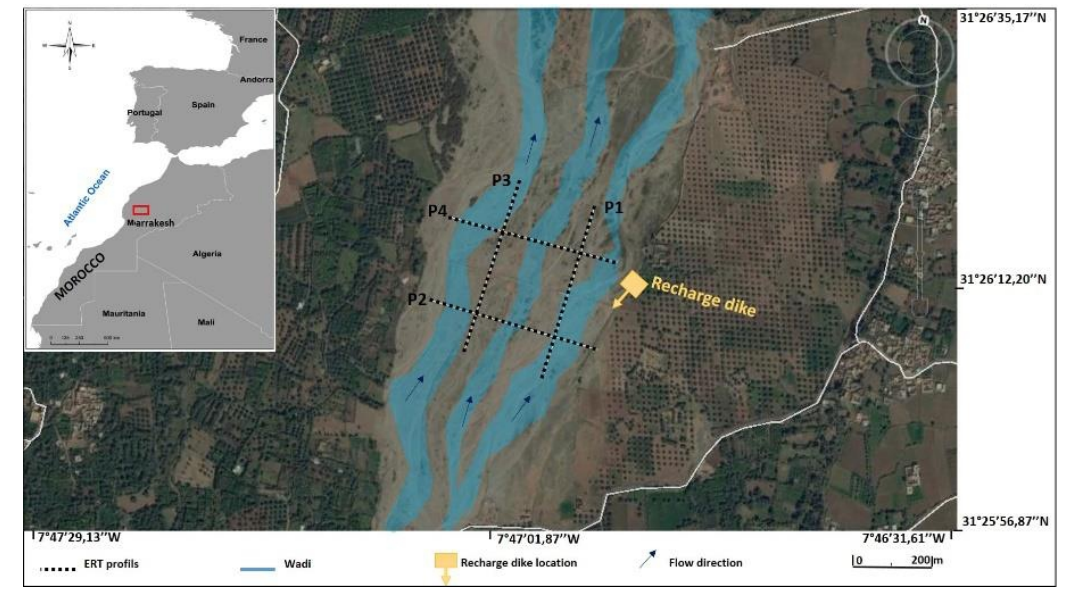

Figure 18: Location of ERT profiles in the study area

\section{Results}

The approach used to select study areas was possible by spatializing the Runoff Coefficient (RC) all over the Ourika-Zat basin. This spatial distribution of this coefficient is used to evaluate the degree of impermeability of a surface what helps to calculate the flows flowed through. The different combinations of the spatial distribution of the three parameters slope, soil texture, and vegetation influence the variability of Runoff coefficient. In this study, the interest was giving to the infiltration by the expression of the rain fraction retained by a given surface, since a low runoff coefficient means that a big part of water was infiltrated. The result map shows that the runoff coefficient varies between a minimum of 0.08 and a maximum of 0.67 (Fig. 6).

The choice of site for the Electrical Resistivity Tomography survey was made based on the results of Runoff coefficient and strengthened by the existence of an artificial groundwater recharge dike built on the Wadi's bed. The profiles were set up about four kilometers east of the village of Sidi Abdellah Ghiat at the bed of the Wadi Ourika. The GIS showed that the runoff coefficient in this area was so low what mean that there is a very high infiltration and permeability of surface formations (Fig. 8). 
The subsurface resistivity data were automatically recorded along the profile at the electrode stations. On each profile, these data were processed and reversed using Geotomo Software's RES2DINV software developed by Loke and Barker (1996). The software uses a least squares optimization technique to invert the apparent $2 \mathrm{D}$ resistivity pseudo-sections required to define the true distribution of resistivity in the subsurface (Loke, 2003; Sasaki, 1992). Least square optimization minimizes the square of differences between the observed and calculated apparent resistivity values. The program automatically creates a 2D model by dividing the subsurface into rectangular blocks (Loke, 2004), and the resistivity of the blocks is adjusted iteratively to reduce the difference between the measured and calculated apparent resistivity values. The program calculates the apparent resistivity values and compares them with the measured data. During the iteration, the modelled resistivity values are adjusted until the calculated apparent resistivity values of the model agree with the actual measurements. The inversion error value varied between 1 and 5.9\% indicating good quality between the measured and calculated apparent resistivity.

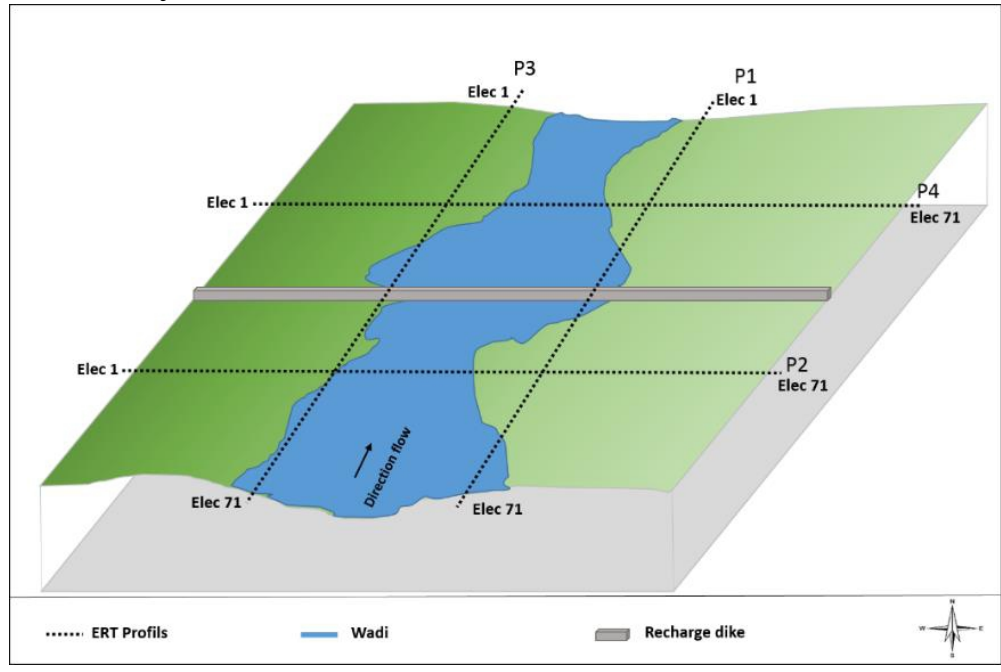

Figure 19: 3D schema of ERT profiles

The analysis of the apparent resistivity data recorded along this profile shows that the values vary from about $8 \Omega . \mathrm{m}$ to $900 \Omega . \mathrm{m}$. This large dispersion of apparent resistivity values led to a much more contrasted subsoil resistivity model. Allowing to identify three entities:

- A superficial resistant ground of variable thickness of about 15 meters with a resistivity ranging from $200 \Omega . m$ to $900 \Omega . m$;;

- A conductive ground of variable thickness ranging from 25 meters at the Talweg pillars to 55 meters in the center of the Wadi. The resistivity of the ground fluctuates between $7 \Omega . \mathrm{m}$ and $40 \Omega$.m; 
- Resistant bodies on either side at the profiles ends, which can correspond, depending on the disposition of the profiles, to arms from the old Wadi in case of a perpendicular profile to the Wadi, or to meander lobes of the old channels in the case of a parallel profile.

\section{Discussion}

Almost the half of the surface studied represents an average runoff coefficient between 0.4 and 0.7 what makes those parts of the basin, in the presence of a rain event, an area conductive to the generation of flash floods, and the other half characterized by low runoff Coefficient located exactly on downstream also on Wadis Bed. These areas are considered as natural recharge areas of the Plio-Quaternary aquifer. Several places with a low runoff coefficient seem good for the application of Electrical Resistivity Tomography but the chosen site was more favorable because of easy access. The four profiles set up in this area were crossing each other like a square as the figure 8 shows.

The Profile 1 was placed perpendicular to the artificial recharge dike, which the features are a length of $355 \mathrm{~m}$, a spacing of 5 meters between the electrodes and a NE-SW orientation (Fig.8).

The results were calibrated using the borehole 3168/53, which is located $620 \mathrm{~m}$ southwest of the profile. This calibration process allowed us to assign the higher resistance level of the Pleistocene as well as the conductor level to the Mio-Pliocene as mentioned above. The piezometric level at this drill hole is 15 meters deep but more as it approaches the Wadi the depth decreases to 3 meters according to some measurements made at the wells of the farmers in the area (Fig. 9).

The clear line between the resistant and conductive formations demonstrated the piezometric level. This boundary can be considered as the wall of the aquifer and the end of the vadose zone. It can be seen that at the terminals of the profile precisely from electrode 11 to 16 and from 51 to 56 the existence of a body more resistant than the surrounding environment. It corresponds to a meander lobe of the old river channel very developed highlighted by the conductive body having a resistivity of $7 \Omega$.m to $18 \Omega . \mathrm{m}$ between electrodes 30 and 40 ranging from 15 meters to 75 meters deep.

Profile 2 was installed upstream parallel to the recharge dike and perpendicular to the 1st profile where the intersection was at electrode 33 and the orientation was SSE-NNW. The same length and acquisition characteristics were preserved to investigate the same depth. The resistivity model showed the same layers highlighted by the 1st profile, a resistant layer extending over the first 10 meters with a resistivity ranging from 300 to 900 $\Omega . \mathrm{m}$. On the field this resistant layer is manifested by blocks of the mother 
rock resulting from the dismantling of the High Atlas chain as well as pebbles and gravel contained in a clay-sand gangue (Fig.10).

According to the borehole of calibration used for the 1st profile, which will be used for the four profiles, it can be seen that this resistant formation belongs to the upper Pleistocene level corresponding to the predominantly sandy alluvium set up by the Wadi. Just below this layer, the resistivity begins to decrease as it enters the aquifer area represented by the conductive layer. The fluctuation of resistivity at this conductive layer was from 7 to $70 \Omega . \mathrm{m}$, corresponding to the Mio-Pliocene extending to 70 meters in depth.

At the level of this thick conductive layer, three bodies that are more resistant than the surrounding environment are visible. The two bodies that are placed at the same depth on either side of the pseudosection correspond to the old arms of the Wadi. While the body at a depth of 60 meters at the center of the profile between electrodes 27-36 may correspond to a lobe of the meander or to the existence of a more or less cemented conglomerate.

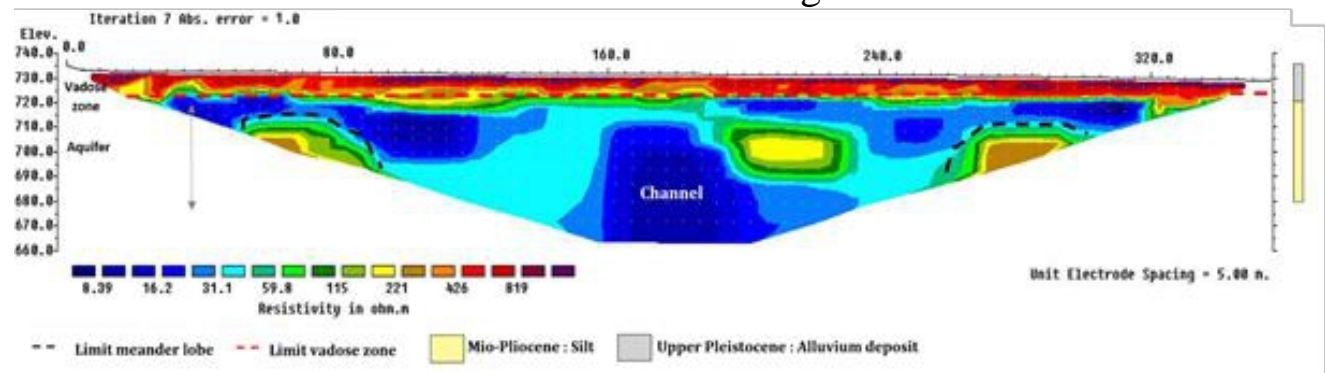

Figure 20 : Profile 1 of Electrical resistivity Tomography

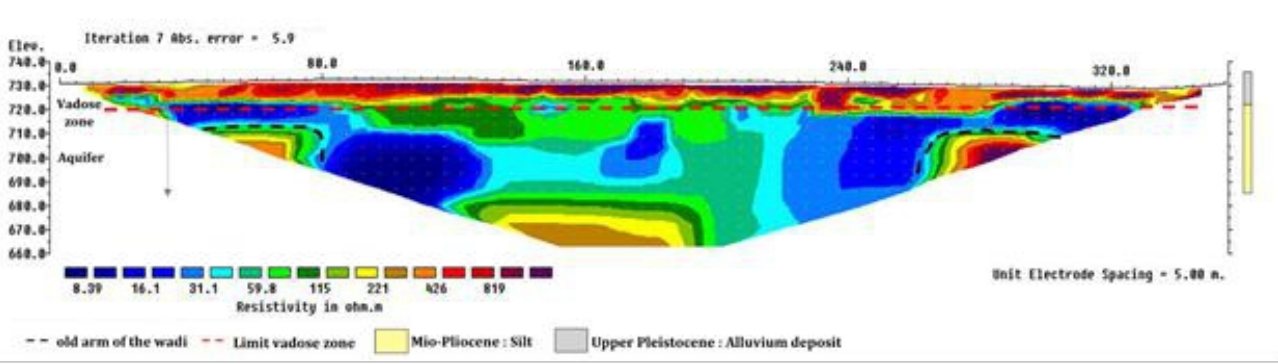

Figure 21: Profile 2 of Electrical resistivity Tomography

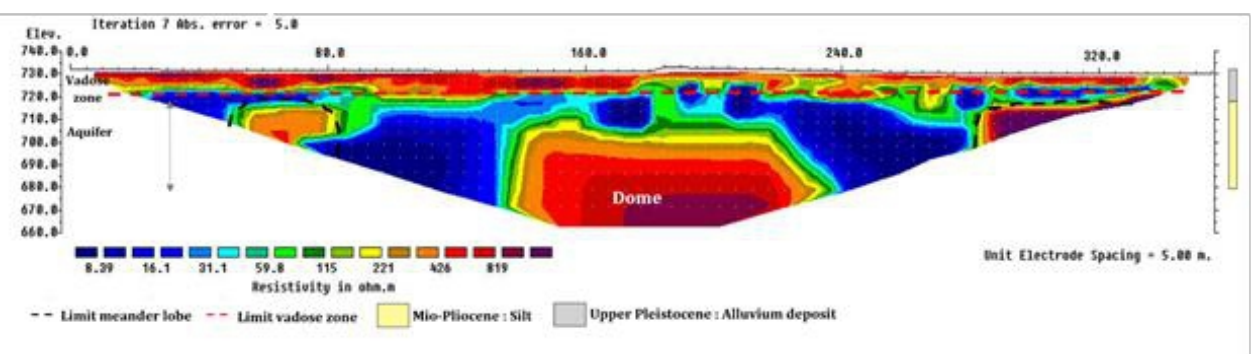

Figure 22: Profile 3 of Electrical resistivity Tomography 


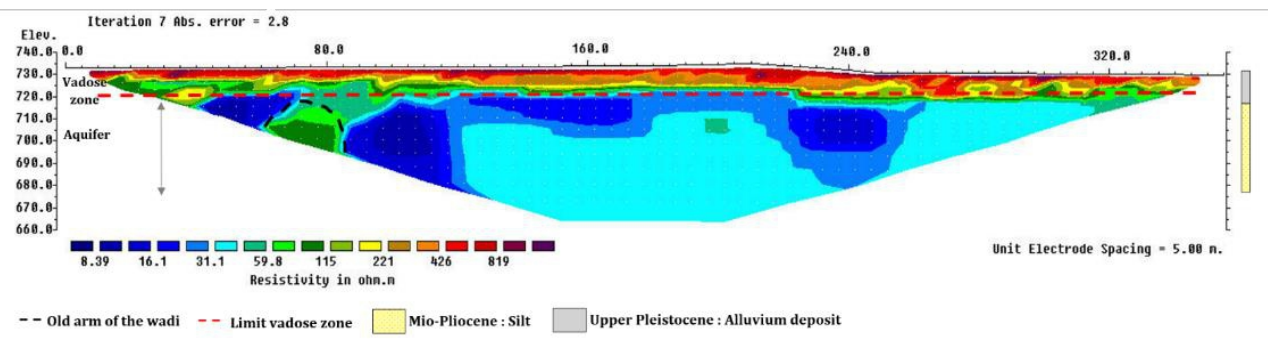

Figure 23: Profile 4 of Electrical resistivity Tomography

Profile 3 it is located perpendicular to the dike and profiles 2, and parallel to profile 1 and the shores of the Wadi. The distance between the first profile and this one is 250 meters, knowing that the width of the bed of the Wadi is 450 meters. The resistivity model shows the two layers encountered in the two previous profiles (Fig. 11).

This profile revealed a large 20 meter thick resistant body at the conductive layer that starts at a depth of 30 meters and extends to depth and those between the 29-45 electrodes. This body can correspond to a MioPliocene well-cemented conglomerate according to the lithostratigraphic log (Fig. 5).

Profile 4 was carried out in parallel with the 2 nd profile and the recharge dike this time downstream, and perpendicular to profiles 1 and 3 . The same length of 360 meters and the same acquisition characteristics have been maintained. The orientation of this profile was SSE-NNW.

On this profile, just one arm of the Wadi was highlighted as it has an absence of a resistant body in the aquifer. According to the resistivity model, profile 4 has a low fluctuation in resistivity. The vadose zone has a resistivity of 400 to $800 \Omega . m$ whose thickness is lower than the other profiles which is 9 meters. However, the aquifer zone is thicker and its resistivity is in the order of 15-40 $\Omega$.m (Fig. 12).

This can be explained by the contribution of the dike to the recharge of the groundwater table, by increasing the thickness of the aquifer and reduces the amount of river inflows from the Wadi what has led to decrease in the vadose zone, which explains its low thickness.

To better visualize the results, the creation of isoresistivity maps was necessary. Seven levels of investigation were subjected to two types of interpolation in order to choose the best and closest to reality (Tab. 3 and Fig. 13). The first interpolation is IDW which is an inverse weighting interpolation of the distance determining the cell values via the linearly weighted combination of a set of sampling points. While the second interpolation is Topo to Raster which is an interpolation method specially designed for the creation of hydrologically correct digital terrain models (DTMs). It is based 
on the ANUDEM program developed by Michael Hutchinson (1988, 1989, 1996, 2000, and 2011). It interpolates the altitude values of a raster by imposing constraints to ensure a reliable connection structure and the correct representation of resistivity horizons from the input isolignes data.

Table 5 :characteristics of the levels of investigation interpolated by IDW and Topo to

\begin{tabular}{cccccccc}
\multicolumn{8}{c}{ Raster } \\
\hline & Level 1 & Level 2 & Level 5 & Level 7 & Level 10 & Level 12 & Level 14 \\
\hline $\begin{array}{c}\text { Depth of } \\
\text { investigation }\end{array}$ & 2,59 & 5,45 & 15,84 & 24,62 & 41,36 & 55,49 & 72 \\
\hline $\begin{array}{c}\text { Number of } \\
\text { measuring points }\end{array}$ & 276 & 276 & 244 & 206 & 138 & 84 & 26 \\
\hline
\end{tabular}

The apparent resistivity value obtained by the ERT profiles represented in the form of isoresistivity maps characterizing a layer with a constant pseudo-depth proportional to $\mathrm{AB}$ distance of 365 corresponding to the length of the profile (Fig.13). The apparent resistivity result of interpolation highlighted the same two areas showed at the pseudo-sections, an area with a higher apparent resistivity between 62 and $700 \Omega . \mathrm{m}$. Another area with a lower apparent resistivity varying between 17 and $50 \Omega$.m, appears up to 10 meters depth. 

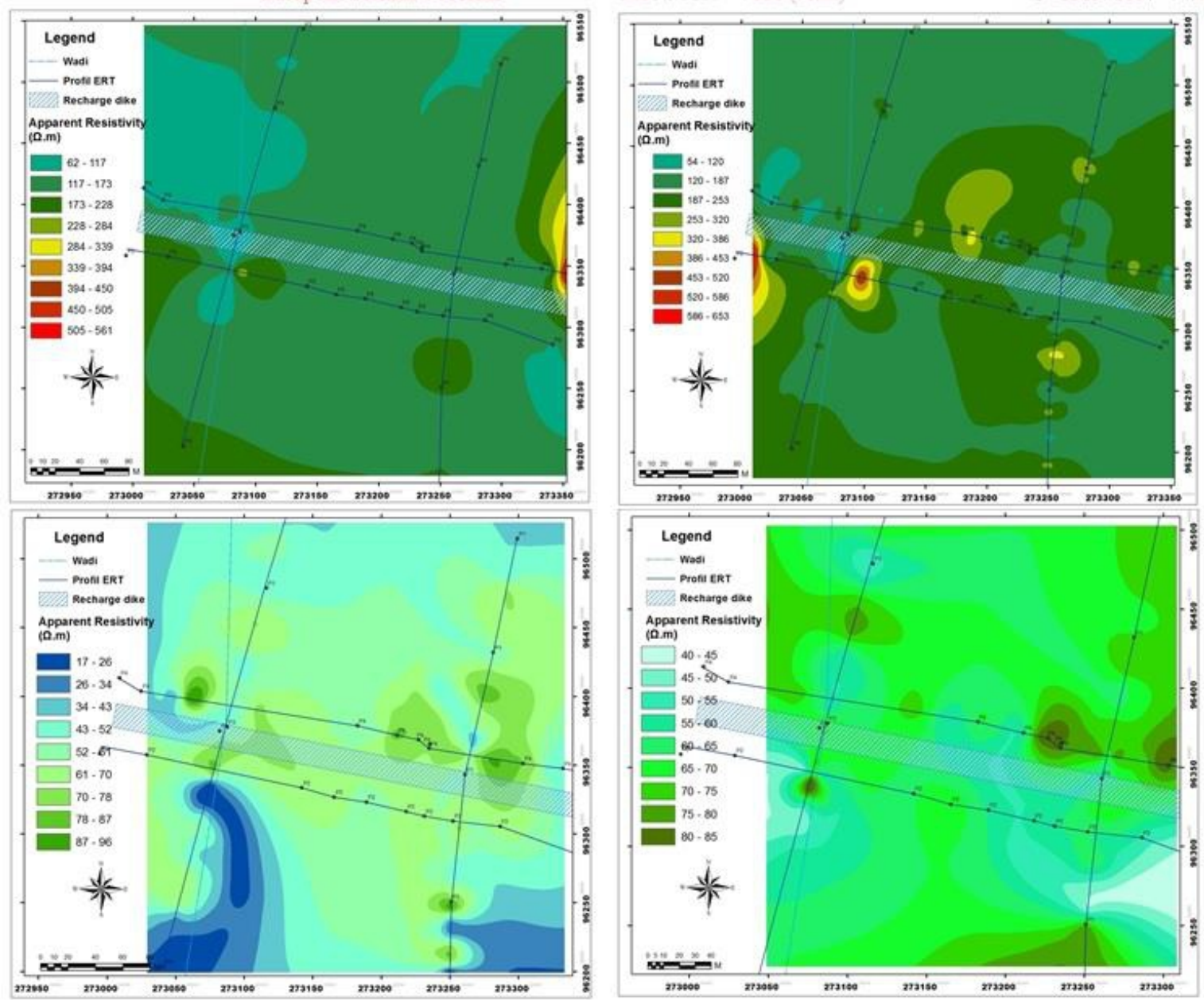

Figure 14: Isoresistivity maps at several depth levels. a) Depth $2.59 \mathrm{~m}$; b) Depth $5.45 \mathrm{~m}$; c) Depth 15.84 m; d) Depth 24 

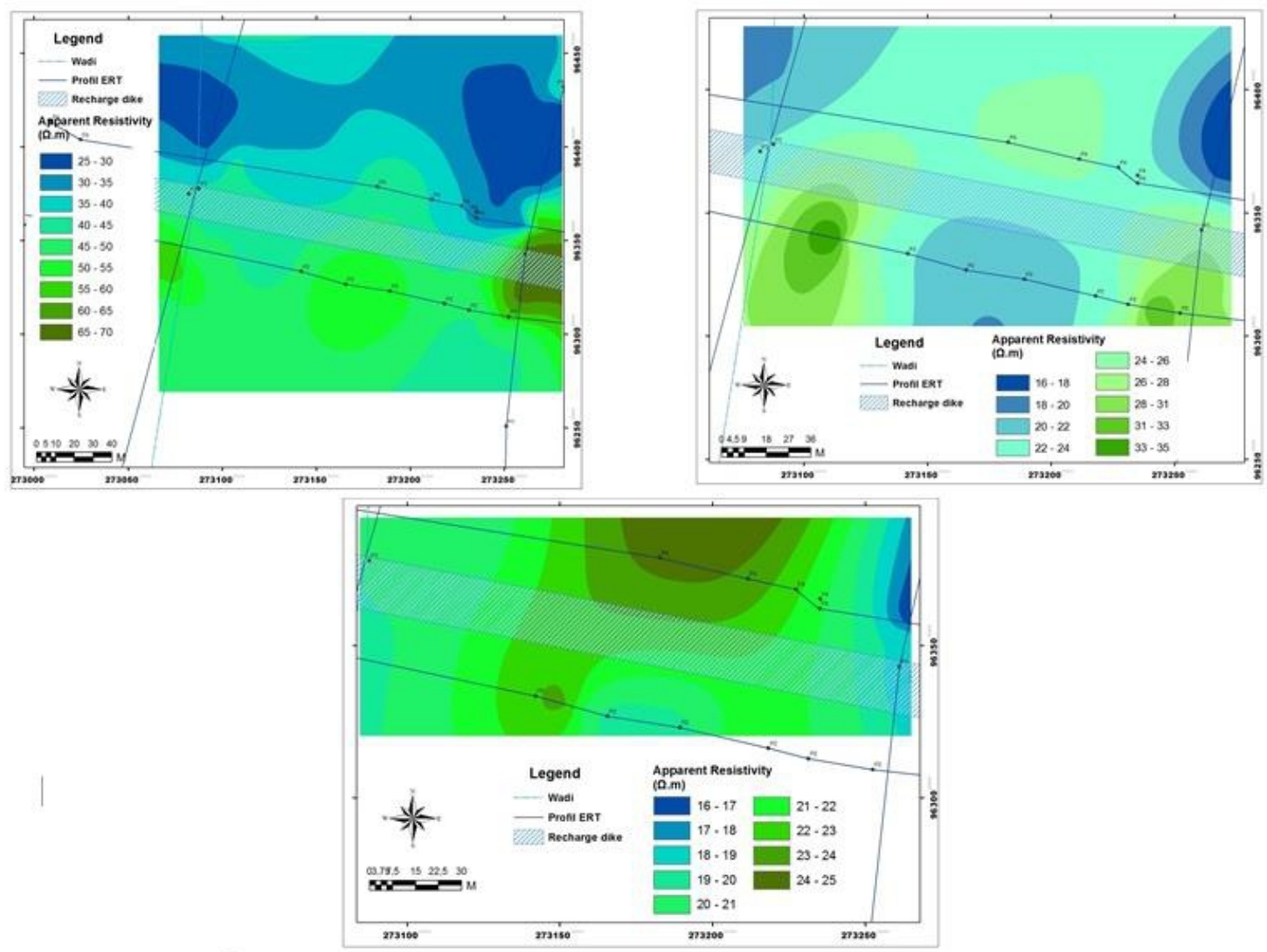

Figure 15: Isoresistivity maps at depth levels.: e) Depth $41.36 \mathrm{~m}$; f) Depth $55.49 \mathrm{~m}$ and g) Depth 72

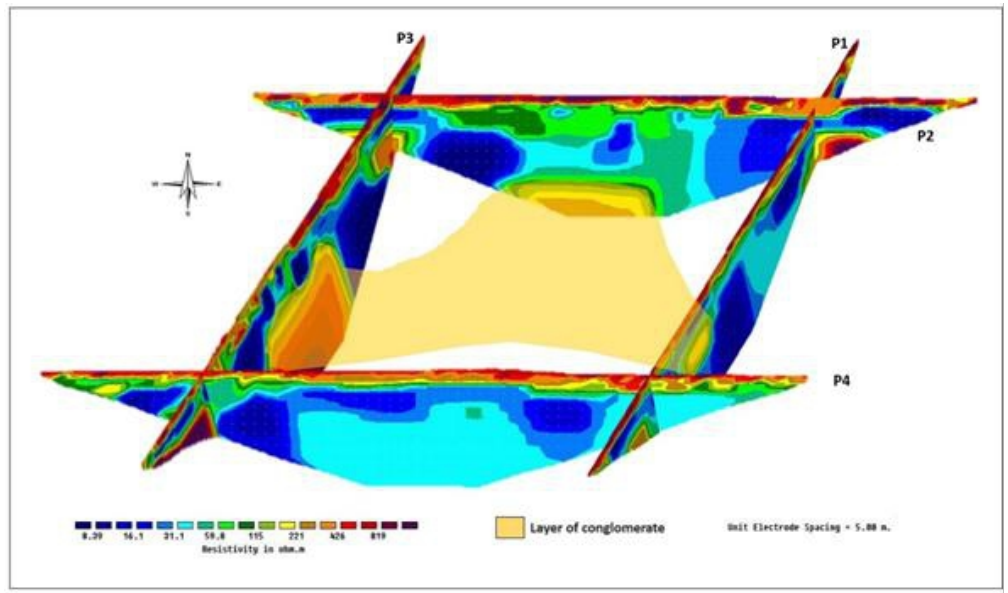

Figure 16: 3D Presentation of the ERT profiles and the conglomerate layer 
According to the correlation with the geological boreholes (Fig.4), high resistivities on the first two levels studied (Level 1 of 2.59 meters depth; Level 2 of 5.45 meters depth) can be attributed to the Upper Pleistocene characterized by alluviums deposit. In the other hand, the, low resistivities located beyond the 5th level, corresponding to above 8 meters of depth, belongs to the Mio-Pliocene mainly formed by sandstone clayey-sands saturated with fresh water what decrease their resistivities (Dutour \& Ferrandini, 1985), knowing that water table depth in this area is beyond $10 \mathrm{~m}$ on average. It is mainly formed also of cemented conglomerates, which is not seen on the isoresistivity maps. For this reason, a 3D intersection of the pseudo-sections is necessary in order to determine the lengthening of the resistant body highlighted at the level of the third pseudo-section (Fig.14).

Similarly, on the same level of investigation, a horizontal variation in resistivity values was noted. Low resistivity values are underlined upstream of the recharge dike on the majority of the investigation levels illustrated by the isoresistivity maps and high resistivity values are underlined downstream.

In figure 14, the resistant body corresponding to the well-cemented conglomerate according to the correlation with the geological borehole (Fig.4 $\& 5$ ), shows an obvious continuity on profiles 1 and 2 . The dispersion of this conglomerate layer increases the thickness by going Nord-West.

\section{Conclusion}

This study was established to characterize the recharge of the PlioQuaternary aquifer at Sidi Abdellah Ghiat region by the combination of two methods the GIS and the Electrical Resistivity Tomography. Therefore, a site selection study was carried out using the GIS method to determine the runoff coefficient. Several sites were chosen for their low runoff coefficient, which means that they are areas of infiltration of precipitation waters. Another advantage that prompted the choice of the study site was the existence of a recharge dike for the Plio-quaternary groundwater, built by the Tensift Watershed Agency (ABHT). This site was the subject of a geophysical study using Electrical Resistivity Tomography (ERT) profiles. The Electrical Resistivity Tomography data collected in the field were represented as pseudosection and as an isoresistivity, maps interpreted using Geotomo Software's RES2DINV software/ ArcGIS software. This provided a model of the resistivity of the subsoil.

The electric tomography profiles were carried out about four kilometers southeast of the Sidi Abdellah Ghiat village. Analysis of the apparent resistivity data recorded along the profiles shows that the values vary from about $8 \Omega$.m to $900 \Omega . \mathrm{m}$. The inversion models were calculated with an error between $1 \%$ and $5.9 \%$ reached after seven iterations. This large dispersion of apparent resistivity values led to a contracted subsoil resistivity 
model. The compilation of resistivity data from the inversion of electrical data shows the existence at the level of the prospected zone of two geoelectrical entities:

- A superficial resistant ground of variable thickness of about 15 meters with a resistivity ranging from $200 \Omega$.m to $900 \Omega$.m, which belongs according to existing reconnaissance drillings to the upper Pleistocene. According to field observations and as long as the profiles are at a wide Talweg, this resistant soil should correspond to the predominantly sandy alluvium installed in the Wadi.

- Under this first terrain, which can be described as alluvial deposit, exist a conductive ground of variable thickness ranging from 25 meters at the Talweg pillars to 55 meters in the center of the Wadi. The resistivity model shows significant lateral and vertical variations in resistivity fluctuates between $7 \Omega$.m and $250 \Omega . \mathrm{m}$ that reflect the local heterogeneity of soil that belongs according to the lithological description of the borehole, to the Mio-Pliocene formation corresponding specifically to the silt and conglomerate. At this same formation, moderately to highly conductive zones were identified, these variations result of the influence of water content underground. On the fourth profile, a remarkable effect of the dike on groundwater recharge evidenced by the decrease in the resistivity and thickness of the superficial resistant ground as well as a partial decrease in resistivities over the entire second conductive ground with an average value of $20 \Omega . \mathrm{m}$.

The applied geophysics detects contrasts in apparent electrical resistivity on either side of the dike. Since the terrain is the same, the variation in apparent resistivity in the same geological formation is due to the variation in water content. This hydraulic installation shows the usefulness of building artificial recharge dikes all along the Wadis as well as considering another alternative to apply in areas of high infiltration outside the Wadis.

\section{References:}

1. Abourida, A., (2007). Approche hydrogéologique de la nappe du Haouz (Maroc) par Télédétection, Isotopie, SIG et Modélisation. Thèse Doctorat D’état, Univ. Cadi Ayyad Marrakech, Maroc. 197 pp.

2. Ambroggi, R., Thuille, G., (1952). Haouz de Marrakech. In, Hydrogéologie du Maroc. Notes et mémoires du Service Géologique du Maroc, 97 pp.

3. Asfahani, J., Zakhem, B.A., (2013), Geoelectrical and hydrochemical investigations for characterizing the salt water intrusion in the Khanasser Valley, Northern Syria, Acta Geophys. 61, 2, 422-444, DOI: 10.2478/s11600-012-0071-3. 
4. Batelaan, O., Wang, Z.M., De Smedt, F., (1996).An adaptive GIS toolbox for hydrological modelling, 3-9, eds., Kovar, K. \& Nachtnebel, H.P., Application of geographic information systems in hydrology and water resources management, IAHS Publ.

5. Bernert, G., Prost, J.P., (1972). Le Haouz de Marrakech et le bassin du Mejjate. Note et Mém. Du serv. Géol. N²31, t2, pp. 239432.

6. Browne, F.X., (1990). Stormwater management, Standard Handbook of Environmental Engineering, ed., R.A. Corbitt, 7.1-7.135, McGrawHill, New York.

7. Chellai, E.H., (1995). Evolution géodynamique des corps sédimentaires méso-cénozoïques du Haut-Atlas de Marrakech. Thèse de 3ème cycle. Univ. Cadi Ayyad, Marrakech, Maroc, 190p.

8. Chellai, E.H., Perriaux, J., (1996). Evolution géodynamique d'un bassin d'avant pays du domaine atlasique (Maroc) : exemple des dépôts néogène et quaternaire du versant septentrional de l'Atlas de Marrakech. C. R. Accad. Sci. Paris, t.322, série IIa, pp. 727-734.

9. Chow, V.T., Maidment, D.R., Mays, L.W., (1988). Applied Hydrology, 498, McGraw-Hill Inc., New York.

10. Conseil Supérieur de l'Eau et du Climat (C.S.E.C) (2001). Plan directeur pour le développement des ressources en eau du bassin du Tensift, 9ème session.

11. Dahlin, T., (2001). The development of DC resistivity imaging techniques. Computers \& Geosciences, 27 (9), 1019-1029. https://doi.org/10.1016/S0098-3004(00)00160-6.

12. DGH, (1994). Etat de la qualité des ressources en eau de la région du Tensift. Année 1993- 1994.42p. (Document inédit)

13. Direction de l'hydraulique, (1980). Notice explicative de la carte hydrogéologique de la plaine du Haouz (Maroc occidental) au $1 / 200.000$. Notes et mémoires du service géologique du Maroc, Rabat, 284, 58 pp.

14. Dutour, A., Ferrandini, J., (1985). Nouvelles observations néotectoniques dans le Haut Atlas de Marrakech et le Haouz (Central Maroc). Apports sur l'évolution récente d'un segmente du bâti atlasique. - Revue géol. dyn. Géogr. phys.,26, 285-297, Paris.

15. Edwards, L.S., (1977). A modified pseudosection for resistivity and induced-polarization. Geophysics 42 (5), 1020-1036. https://doi.org/10.1190/1.1440762.

16. Fetter, C.W., (1981). Determination of the direction of groundwater flow Groundwater Monitoring \& Remediation, Vol.1, No. 4, pp. 2831. https://doi.org/10.1111/j.1745-6592.1981.tb00813.x.

17. Freytet, P., (1984). Les sédiments lacustres carbonatés et leur transformation par émersion et pédogénèse. Importance de leur 
identification pour les reconstitutions paléogéographiques. Bull. Centre Rech. Explor.-Produc. Elf Aquitaine 8: 223-247.

18. Giang, N.V., Duan, N.B., Thanh L., Hida, N., (2013), Geophysical techniques to aquifer locating and monitoring for industrial zones in North Hanoi, Vietnam, Acta Geophys. 61, 6, 1573-1597, DOI: 10.2478/s11600-013-0147-8

19. Kabbaj, A., Zeryouhi, I., Cralier, Ph., Marcé, A., (1978). Contribution des isotopes du milieu à l'étude des grands aquifères Maroc. In Isotope Hydrology, A.I.E.A., Vienne, 941 - 524.

20. Liu, Y.B., Gebremeskel, S., De Smedt, F., Hoffmann, L., Pfister, L., (2003). A diffusive transport approach for flow routing in GIS-based flood modelling, J. Hydrol., 283, 91-106. https://doi.org/10.1016/S0022-1694 (03)00242-7

21. Loke, M.H., Barker, R.D., (1996). Rapid least-squares inversion of apparent resistivity pseudosections by a quasi-Newton method. Geophys. Prospect. 44, 131-152. https://doi.org/10.1111/j.13652478.1996.tb00142.x

22. Loke, M.H., (2003). Rapid 2D Resistivity \& IP Inversion using the least-squares method. Geotomo Software. Manual.

23. Michard, R., (1976). Eléments de géologie marocaine. Notes et mém. Serv. géol. Maroc.

24. Moukhchane, M., (1983). Contribution à l'étude des réservoirs profonds de la bordure nord de l'Atlas entre Demnate et Imintanoute (Maroc). Thèse de 3ème cycle. Besançon. 119p.

25. Piqué, A., Michard, A., (1981). Les zones structurales du Maroc hercynien. Sci. Geol. Bul., no 34,2, 135-146

26. Philip, G.M., Watson, D. F., (1982). A Precise Method for Determining Contoured Surfaces." Australian Petroleum Exploration Association Journal 22: 205-212. https://doi.org/10.1071/AJ81016.

27. Razoki, B., (2001). Mise en place d'un système de gestion de base de données pour la gestion des ressources en eaux souterraines de la plaine du Haouz (meseta occidentale, maroc). Thèse Univ. Cadi Ayyad, Marrakech, Maroc, 166p.

28. Sasaki, Y., (1992). Resolution of resistivity tomography inferred from numerical simulation. J. Geophysical prospecting. doi.org/10.1111/j.1365-2478.1992.tb00536.x

29. Sharma, K.D., (1986). Runoff behavior of water harvesting microcatchment. Agric. Water Manage. 11, 137-144. https://doi.org/10.1016/0378-3774(86)90026-0.

30. Shereif, H.M., (2014). Investigation of rainfall-runoff modeling for Egypt by using remote sensing and GIS integration. Catena journal. dx.doi.org/10.1016/j.catena.2014.04.011 
31. Sinan, M., (2000). Méthodologie d'identification, d'évaluation et de protection des ressources en eaux des aquifères régionaux par couplage et SIG, de la géophysique et de la géostatistique. Application à l'aquifère du Haouz de Marrakech (Maroc). Thèse Université Mohammed V. Rabat, Maroc.

32. Wang, Z.M., Batelaan, O., De Smedt, F., (1997). A distributed model for water and energy transfer between soil, plants and atmosphere (WetSpa), Phys. Chem. Earth, 21(3), 189-193. https://doi.org/10.1016/S0079-1946(97)85583-8.

33. Watson, D. F., Philip, G.M., (1985). A Refinement of Inverse Distance Weighted Interpolation." Geoprocessing 2:315-327. 